\title{
Tourist-beach protection in north-eastern Sicily (Italy)
}

\author{
Stefania Lanza • Giovanni Randazzo
}

Received: 5 March 2012 /Revised: 24 May 2012 / Accepted: 3 September 2012 /Published online: 27 September 2012

(C) Springer Science+Business Media B.V. 2012

\begin{abstract}
Sicily is the largest island in the Mediterranean, and tourism represents the most important income in the regional budget. This is due to a mild climate, to its considerable archaeological and cultural heritage, but above all to the beaches, which host visitors for most of the year. Nevertheless, Sicily has no official Integrated Coastal Zone Management (ICZM) policy and also lacks an overall plan for coastal protection. In 2000, however, driven by the EU, a process of selection of projects based on objective parameters was initiated. Not all of these projects have had the expected results and some are yet to be completed. One of these is Giardini Naxos, Taormina beach, one of the main tourist resorts in Sicily. There, due both to the incorrect position of the port structure and to the rapidly increasing coastal urbanization (second homes, hotels and waterfront), a process of coastal erosion has started, the beach has disappeared, and the promenade has been damaged. To rebuild the shore in order to protect the structures behind it and to restore the coast for beach goers, a submerged barrier (like a reef) was designed to protect an artificial beach replenishment using local and remote sands, mined from the continental platform bottom and compatible both in terms of composition and grain size. Even though the results were excellent during the first stages of the project, towards the end, financial support disappeared and the funds were allocated to other projects. This experience in Giardini Naxos
\end{abstract}

\footnotetext{
S. Lanza $\cdot$ G. Randazzo

Department of Earth Sciences, University of Messina,

Messina, Italy

S. Lanza

e-mail: lanzas@unime.it

G. Randazzo ( $\square)$

Dipartimento di Scienze della Terra, Università di Messina,

Via F. Stagno d'Alcontres, 31,

98166 Messina, Italy

e-mail: grandazzo@unime.it
}

illustrates the ineffectiveness of defensive action in the absence of coastal planning that takes into account the sustainability of interventions on a regional basis both from a structural and an economic standpoint.

Keywords ICZM · Beach nourishment · Tourist beach

\section{Introduction}

The increasing pressure on the coastal area from inland can cause a permanent impact, which can endanger future safety (Van Vuren et al. 2004). For this reason, there is growing concern about the implications of present and future environmental changes for nature conservation and the welfare of human communities.

Currently, the shoreline is not merely a point of unstable equilibrium between the sea and the land which is subject to great variability depending on their relative movements, but rather it is a breaking point for social, biophysical, economic, and technological changes. Therefore, it is essential to provide policy-makers with a better understanding of the consequences of different management options because, above all, anthropogenic factors exacerbate natural processes (Meur-Férec et al. 2008) affecting the coastline.

The erosion crisis affecting numerous coastlines has been noticeably worsened by structures/actions designed to protect the coast (Deboudt 1999; Deboudt 2002; Miossec 1998), influencing both longshore and offshore transport. In recent years, it has been pointed out (Eurosion European 2004) that there is a direct cause and effect association between coastal erosion and construction of various types (tourist, industrial, residential), railway structures, roads, highways, port facilities, and intensive agriculture. Erosion has also occurred where hard structures (seawalls, groins, and breakwaters) have been built to protect the settlements themselves that previously caused the erosion. 
This building-chain system shows a clear lack of basic planning and also a lack of foresight, since the defence factors should not only be functional in the geomorphologic, sedimentological, and hydraulic environment, but should aim primarily at maintaining the functionality of the protected shoreline. In Sicily, especially in the past, primary attention was paid to hydraulic-structural workings, without considering two basic aspects: the first being related to the fact that often hard structures, variously oriented, protected the area immediately behind it, while down-drift erosion processes continued; and the second being due to the lack of knowledge about the real situation of the protected area, using hard structures which were dangerous and unsightly and sometimes affected the local economy by damaging the beauty of the area (Randazzo and Lanza 2011; Randazzo et. al. 2008). This represents a weak point, especially in terms of management, above all in a coastal context, such as the Sicilian one characterized by extreme complexity composed of:

- 114 coastal municipalities;

- $1623 \mathrm{~km}$ of total length of coastline (including smaller islands);

- $93 \%$ natural (26\% high coast and $74 \%$ low coast) and $7 \%$ is artificial.

Furthermore, between the late 1970s and middle 1980s, urban pressure, consisting of holiday homes, tourist resorts, promenades and ports, intensified this erosive process and more than $1 / 4$ of the coastal area has retreated. In response to this process, despite that the beaches are one of the main tourist attractions, the only protective measures, almost always implemented under emergency pressure and without regional planning, were groins and breakwaters that have ruined the landscape and the quality of the beaches, often transferring the erosion process towards neighbouring villages. These, to protect themselves, used the same techniques, and triggering the same mechanisms.

Only in the year 2000, following a specific EU competition, did the Sicilian Regional Government start allotting funds for coastal protective intervention following a precise guideline which stressed the need to remove the causes of erosion instead to operating on the effects. The approach was to encourage the use of soft protective structures rather than harder ones; the former were represented by artificial replenishment eventually protected by a submerged barrier, while the latter were represented by groins, breakwaters, and seawalls. After an "apparently" motivated selection, the Sicilian Regional Government financed 17 intervention projects, but only a few solved the problem, while the others failed in a more or less obvious way. Only few projects correctly fulfilled the aims of the guideline; many of them, made up of material coming from inland quarries, were associated an artificial replenishment with specific shaped groins (islands) and only four were associated a beach replenishment with a submerged protection (reef barrier type). Regarding the 17 interventions funded in 2000, this paper will discuss the origins and developments affecting the activities conducted in the Bay of Giardini Naxos (northeastern Sicily), underlining the causes that determined the erosive process, the types of measures laid out, and the development of the project itself from a bureaucratic as well as technical standpoint.

\section{Tourist framework}

Sicily, the largest island in the Mediterranean Sea, has constantly been visited by many tourists because of its beauty and its varied landscape, with attractive archipelagos of small islands surrounding it, and its cultural and archaeological heritage. The most basic tourist attractions are the beautiful beaches (Fig. 1). In the last 10 years the tourist trend in Sicily has registered a regular presence of about 15 million visitors corresponding to a presence of about 5 million people who spend at least three nights in an official tourist structure.

The municipality of Giardini Naxos is a small town (about 10,000 inhabitants), located in the northern part of the Ionian coast of Sicily, between the cities of Messina and Catania. This small town, together with the neighbouring municipality of Taormina, both on the Bay of Giardini Naxos, became one of the most important tourist attraction in Italy after War World II.

Since 1500 , Sicily has been considered a necessary stop on the Grand Tour of many foreign visitors passing through the Strait of Messina and started an educational journey which passed by Taormina, as recorded in writings and watercolours (from Bruegel to Hamilton and from Saint Non to Houel and to Gigault de la Salle).

At the beginning of the 20th century, Taormina began to serve as the holiday place for kings and actors and, until the 1970s, traces of these glamorous activities continued. Later, a shift in tourist trends changed the visitors of the area, which has survived to different levels of crisis.

The two municipalities are located on the Bay of Giardini and the tourist flow, which peaks between May and October, registers about 442,000 visitors, who stay in the area for an average 4.12 days, totalling more than 1.8 million visitors a year (A.A.S.T 2010).

During the first decades of the 1900s Giardini Naxos maintained its structure as a fishing village, dedicated mainly to the cultivation of citrus and the production of terracotta. However, the implementation of an economic model based on tourism shifted the territorial organization to the leisure industry, transforming large areas and coastal zones (rural and natural landscapes) into urban spaces of primary and secondary residences and tourist sites with associated services (Tintoré et al. 2009). 
Fig. 1 Mediterranean Sea

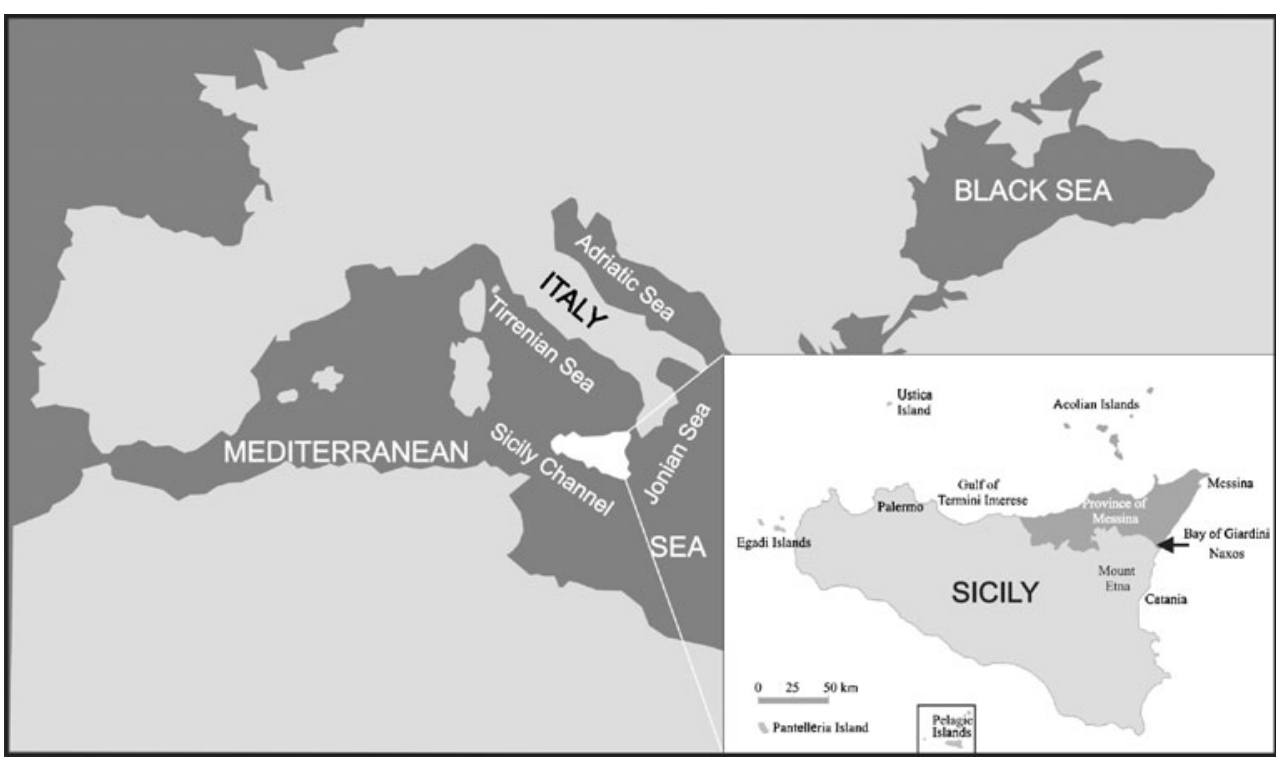

\section{Geographical setting}

The Bay of Giardini Naxos has a beach backed by a promenade (Tyndaros), hotels, and residential houses, and is bounded by two rocky headlands: Cape Taormina in the north and Cape Schisò in the south. The area hosts many archaeological treasures, such as the Greek theatre, the Roman baths, and the Greek port of Naxos, but also several clubs, luxury shops, and more than 100 hotels, six of which are five star.

The 3-km-long beach, with a NE-SW direction is cut by two small waterways, Sirina and San Giovanni, which with their limited fluvial input guarantee extraordinary water clarity. In the northern part of the bay, there is a semi-artificial extension of the beach locally known as Porticciolo (literally little port) of Saia.

The Bay has a maximum depth of c. $10 \mathrm{~m}$ at $500 \mathrm{~m}$ from the coastline which reduces to $5 \mathrm{~m}$ at $150 \mathrm{~m}$ from the coastline. The main winds, coming from the first and the second quadrants, until a recent past, thanks to the lack of human structures, moved the sediments alternatively from north to the south and from the south to the north (Amore et al. 1988).

In prehistory, the Bay of Giardini did not exist as we know it today, being a continuous coastal stretch starting from Capo Taormina and reaching southward to the base of Mount Etna. The whole area was dominated by the alluvial plain of the Alcantara river flowing into the sea some $100 \mathrm{~m}$ south of Cape Schisò. During prehistory, lava flowing from the crater of Mount Etna reached the coastline to form the promontory of Capo Schisò and the Bay of Giardini Naxos.

At the beginning of the last century, the bay had only one continuous beach (falcate), partially protected by several rocks in the central area, which emerged from the sea floor and rose above the sea level (Photo 1). The bay was also still open to the solid materials coming from the Alcantara river.
This is confirmed from (Chelussi 1912; D'Arrigo 1936), who reported in the sediments deposited on the beach of Giardini Naxos the presence of colourless green pyroxene that the clearly comes from Mt. Etna.

\section{The recent development of the coastline}

In 1958 on Capo Schisò, the outer mole of the homonymous port started to be built and at the end of the 1970s it was lengthened $(250 \mathrm{~m})$, even though it has never been finished and it is still not a safe port for the summer months. After the construction of the mole, the sediment flow coming from the Alcantara river was permanently blocked. Because of this the sediments that were present along the beach of Giardini were no longer shifted from south, but rather transported mainly by the currents coming from the north, and heading towards the south, leaving (north of Villagonia) totally pebbly beaches in the northern sector (Fig. 2).

In the central sector of the bay, which is more exposed to sea storms from the East:

- the northern part has narrow beaches protected by several rocks standing above sea level that after the human changes remain more or less stable;

- the southern sector, totally exposed to eastern sea storms and limited by the promenade, underwent severe erosion, which caused the loss of the beach itself and the collapsing of the promenade, the distribution of sediments towards the port of Schisò and off the coast through channels suborthogonal to the coast, identified by (D'Arrigo 1936).

In the southern part of the bay near the Port of Schisò a wide beach was formed and this affected the productivity of the structure itself. 
Photo 1 Emerged rocks in the central part of the bay

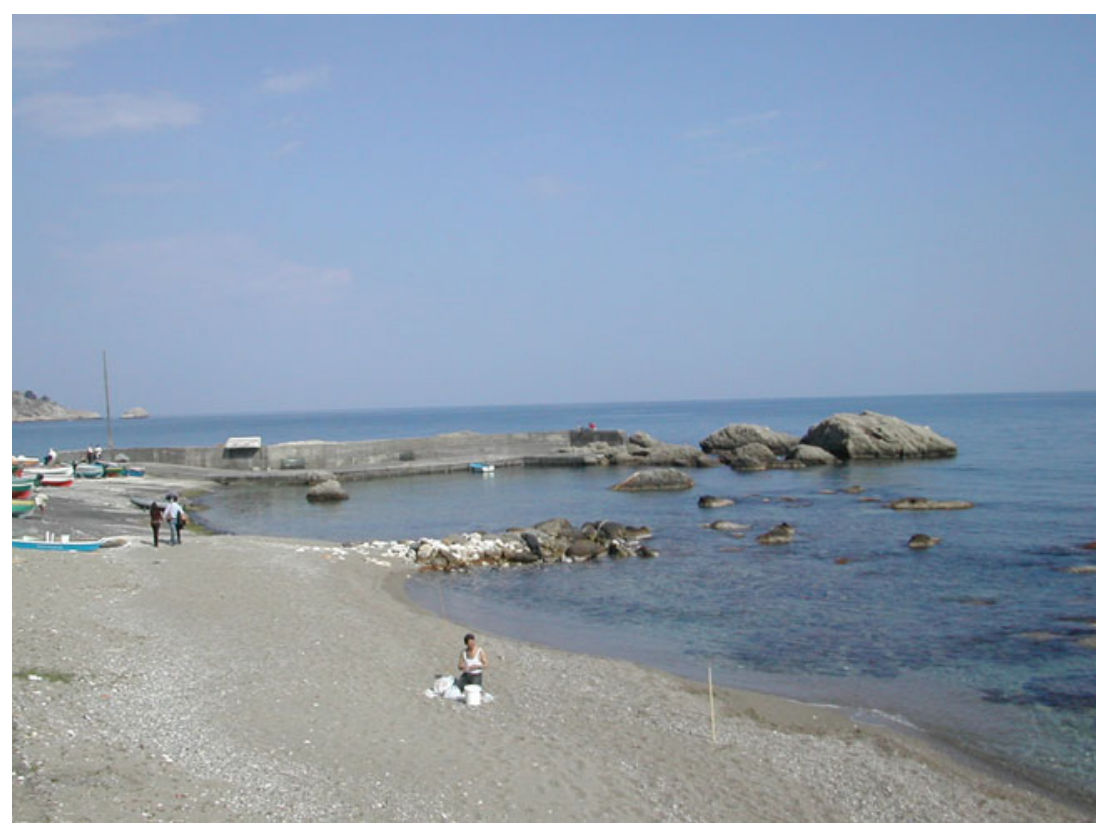

During that decade, which coincided with the economic boom, the area saw the building of new houses, restaurants, hotels, and a promenade along the shore that today extends along the Bay of Giardini Naxos. All these structures were in fact threatened by the erosive process, particularly in the southern part of the central sector, where the beach completely disappeared and the promenade collapsed.

During the last two decades of the 20th century, in order to protect the coastline from erosion, local administrators created three breakwaters and three groins that passively stopped the erosive process, occasionally protecting the promenade (it nonetheless collapsed three times), but without helping to create a beach, so that tourism in the town went through long periods of crisis and decay.

\section{Discussion: the protection system}

In the EU competition of the year 2000, launched by the Sicilian Regional Government, the municipality of Giardini Naxos submitted its own project, accompanied by an hydraulic and sedimentological - geomorphic study, autonomously financed (the only one in Sicily). This study on the erosive process of the bay, had been undertaken to design a protection system that would restore the balance of the shoreline while allowing tourists to use the beach. The aim of the project was to improve the aspect of the shore, to moderate wave action within the protected area, and to limit the dispersion of sediments in the southern part of the bay.

The study underlined the development described above, and, since it is not possible to remove the mole of Schisò or to retreat the promenade near the beach, a suggestion was made to protect the southern sector of the central area by using a composite system:

1. The creation of an 800-m-long parallel artificial reef located along the $-5 \mathrm{~m}$ isobaths at a distance of around $100-150 \mathrm{~m}$ from the shoreline, meant to reduce by $1 / 3$ the wave climate naturally present along the coast.

2. The artificial beach replenished with materials from the sea bed, both local (Bay of Giardini Naxos) and remote (submerged deposits outside the Bay) for an overall amount of about 250,000 cubic metres. Since the area does not have suitable materials, either texturally or compositionally, it was necessary to identify both on a local and on a regional level the deposits necessary for the intervention. In the Bay of Giardini, two deposits were indentified inside the mole of Schisò and just near the dock itself at the $12 \mathrm{~m}$ isobath. Research on a regional level was conducted independently by a company on a national level (Arenaria S.r.l.) which located the compatible materials in the Termini Imerese Gulf.

3. The removal of the three breakwaters, submersion of the three groins and the re-use of volcanic rocks to create the reef barrier.

The beach replenishment choice was made for environmental reasons, to restore a beach reserve of a couple of dozen metres that would conform to the physiological seasonal transfer between the emerged and submerged beach, preventing erosion.

The new beach enabled us to move the promenade away from the sea, providing shelter from the most violent storms.

Moreover, the beach-replenishment technique, considering the peculiar geometry of the physiographic units, was facilitated by the limited offshore transport compared to the 
Fig. 2 The Bay of Giardini Naxos: winds, currents, and coastal development: the number of the blue arrows is related to the frequency of the winds affecting the bay

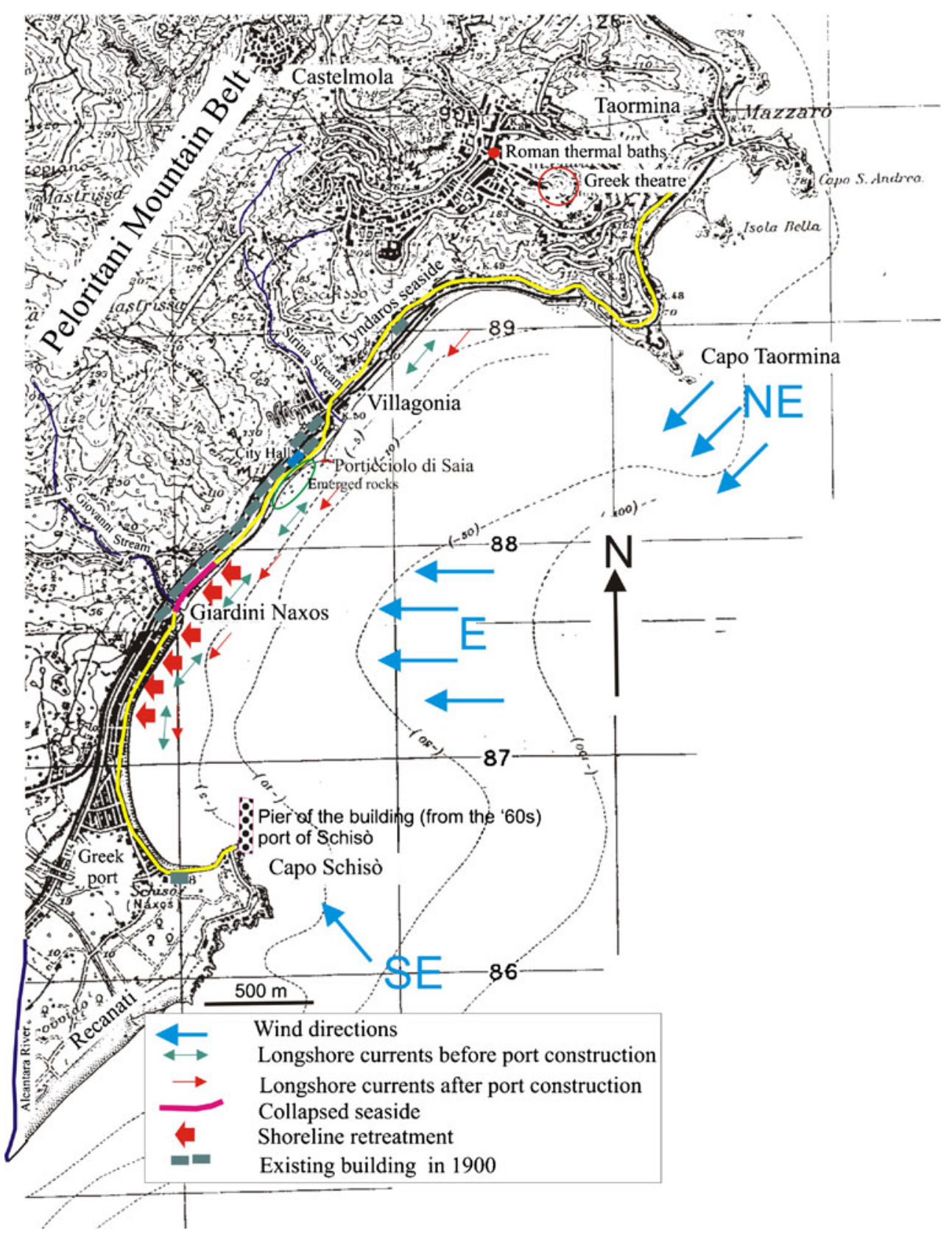

longshore one. In this context, the submerged groins will reduce southward transport, maintaining the sediments in the deposit area. The resources for first step of the replenishment were found in the Bay of Giardini Naxos, consisting of sediments that had been eroded over the past few years along the coastline. The material, of which there was about 70,000 cubic metres, was adequate for the first phase of the replenishment but not to complete the work and its subsequent recharge. It is also important to note that in this specific case, using the sediments directly or indirectly trapped by the mole of Schisò, we re-establish the natural feature of the southern part of the bay; and we furthermore allow the use of the mole for summer use.
The choice of an artificial reef enabled a selective dissipation of the swell break that starts at $170 \mathrm{~m}$ from the shoreline near its external foot and ends at its peak at $150 \mathrm{~m}$ from the shoreline. The barrier also corrects and makes a regular direction of the swell within the protected area, further limiting the longitudinal displacement of the sediments.

The whole project of 5 million $€$, proved impossible to finance in one settlement and was therefore managed in three different phases during which a monitoring and maintenance plan was followed (Fig. 3). In the first phase, concerning the southern part of the project, a section of the barrier reef was built (around $250 \mathrm{~m}$ ), using natural volcanic 
Fig. 3 Time course of the project from Google Earth
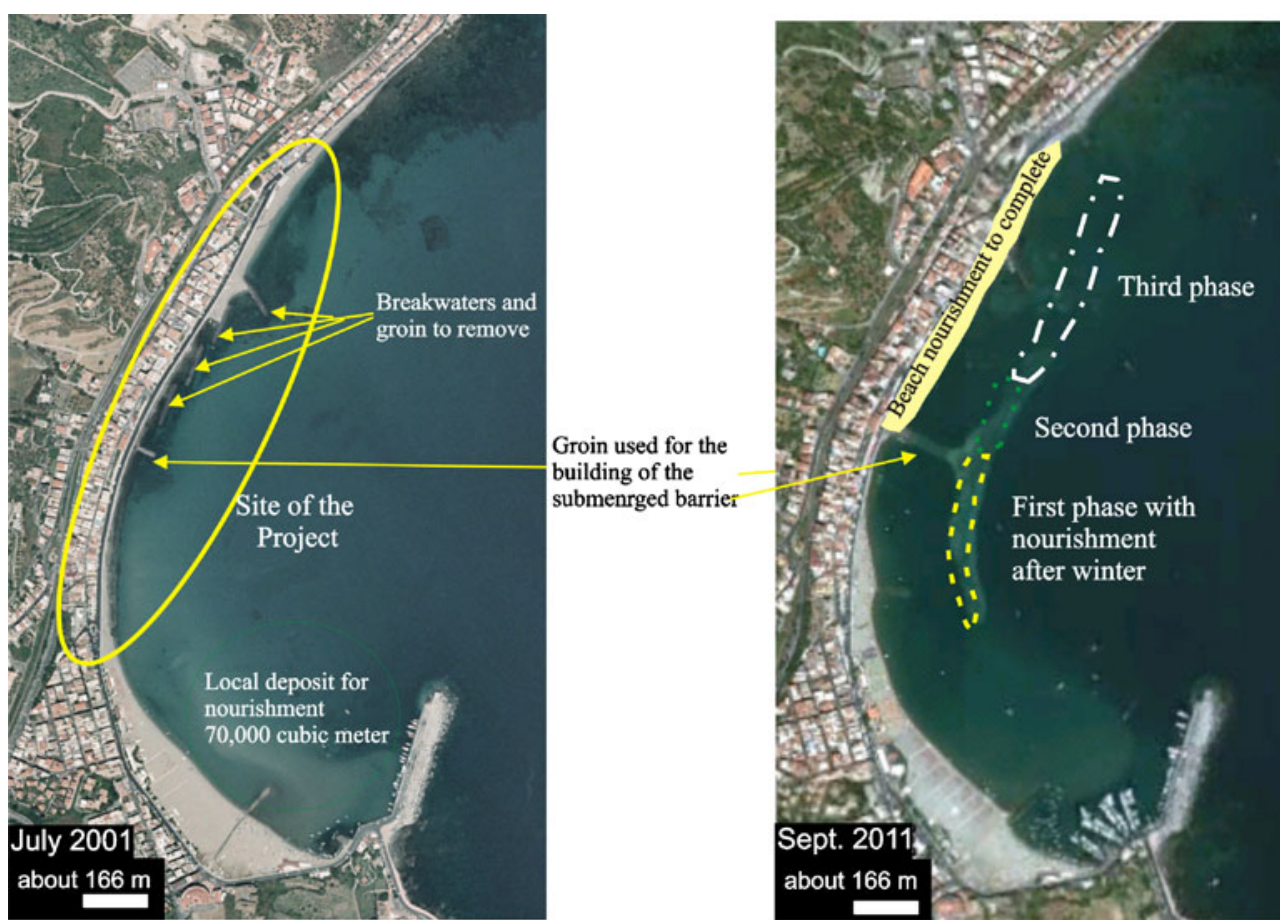

blocks, brought from land using an existing groin, and the beach was replenished, from the sea using a sorbona,with about 70,000 cubic metres of materials in November 2004 (Photos 2 and 3). During the second phase, one of the three breakwaters removed and the reef barrier was lengthened by $150 \mathrm{~m}$. This second phase ended in 2008 and because of financial problems and the beach replenishment was discontinued. The third and final phase of the project will involve finishing the submerged barrier $(400 \mathrm{~m})$, the removal of the other two breakwaters, the submersion of the groins, and the beach replenishment of the protected area. This will commence when the regional government releases the funds needed to complete the project.

A seasonal bathymetric and sedimentological monitoring both started towards the end of the first step of the project so as to provide an in situ model to proceed with the project and above all to identify recharge needs and the dispersion of the sediments. Continuous monitoring provided effective data for the analysis of the total stability of the project, which allowed variations to be introduced in order to improve the initial project and thus facilitate the second step. Continuous analysis of the system and the modelling, thanks

Photo 2 Old breakwaters and eroded area

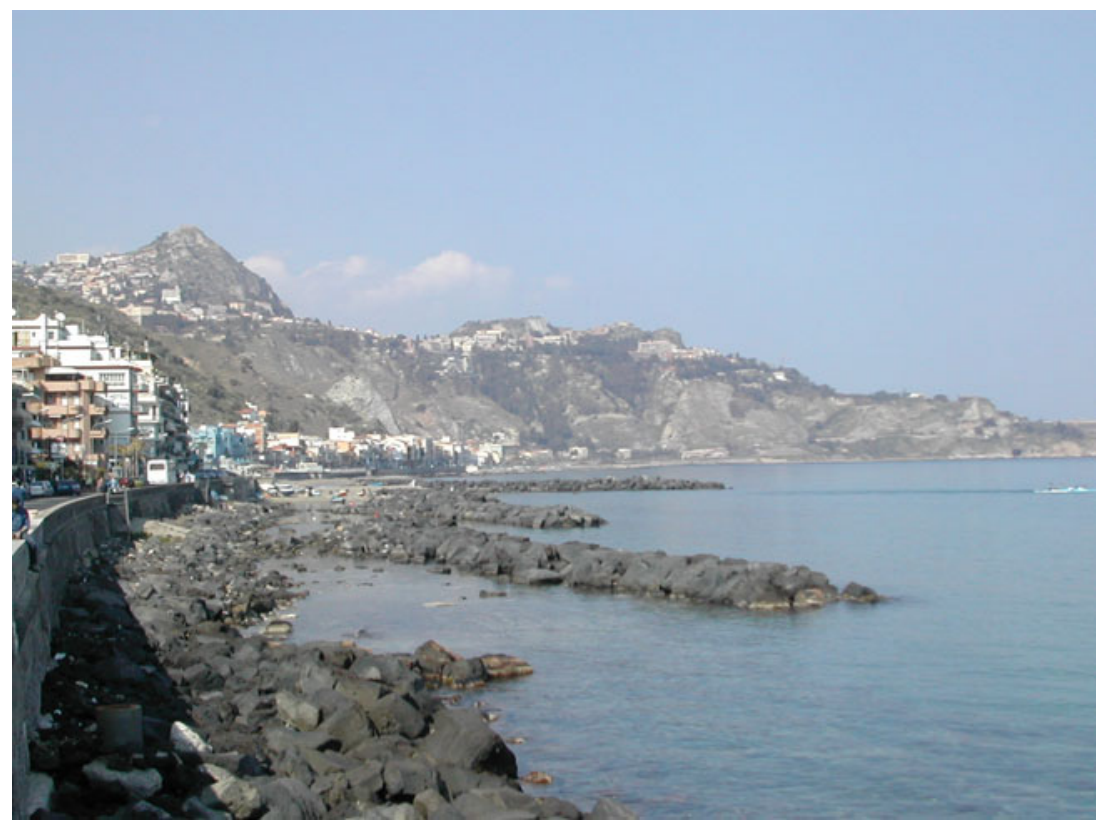




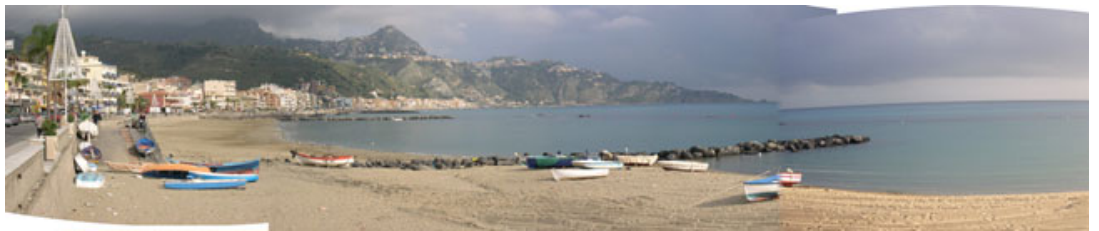

Photo 3 The protected area after the first phase of intervention (December 2004). Few days after the completing of the protection and the replenishment of the south part of the beach of Giardini Naxos, the area was subjected to a very severe storm. The picture shows the

to MIKE21 software, improved the project, enhancing the creation of a system inspired by the integration of the work into the geomorphologic-sedimentological context (Fig. 4).

With this procedure, during the monitoring range, it was determined that, to maintain the artificial beach replenishment and the environmental quality of the project, an annual recharge between 10 and $20 \%$ would be necessary. We also
50-60 $\mathrm{m}$ beach stable after the event and the transparency of the water which represents the high quality (compatibility) of the sediments used for the replenishment

noted that the material spilled out between the summer and autumn of 2004 without a suitable recharge has gradually vanished and more than $50 \%$ has been removed from the emerged beach and deposited in opposite sea beds, on the foot of the reef barrier and protected by it or near the mole of Schisò in its original position. For this reason we suggested using an allochthonous deposit, for the entire project,
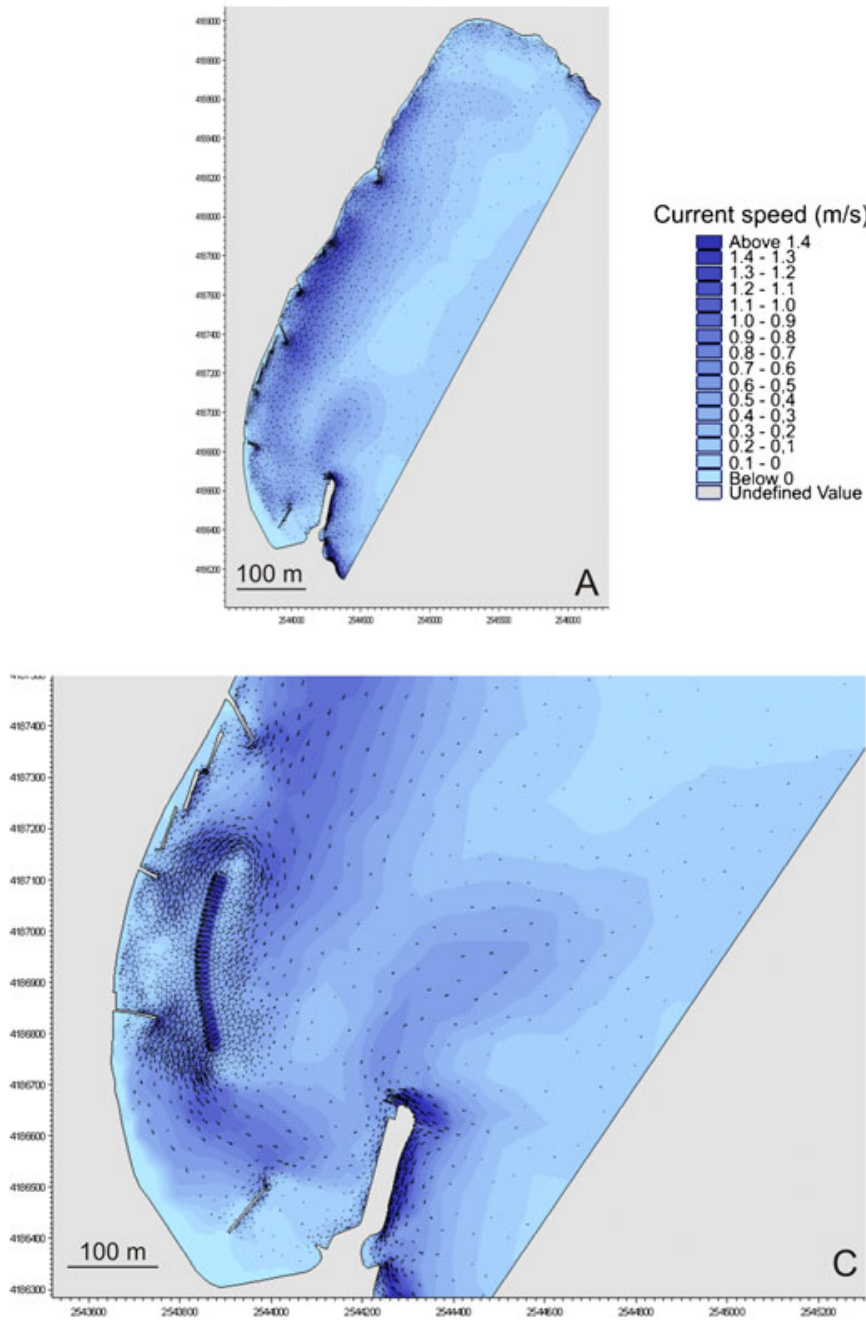

Fig. 4 Comparison among different project solutions under the same wave conditions $\left(90^{\circ}\right.$ current flow): a the whole Bay of Giardini Naxos without any intervention, $\mathbf{b}$ particular of the southern part of
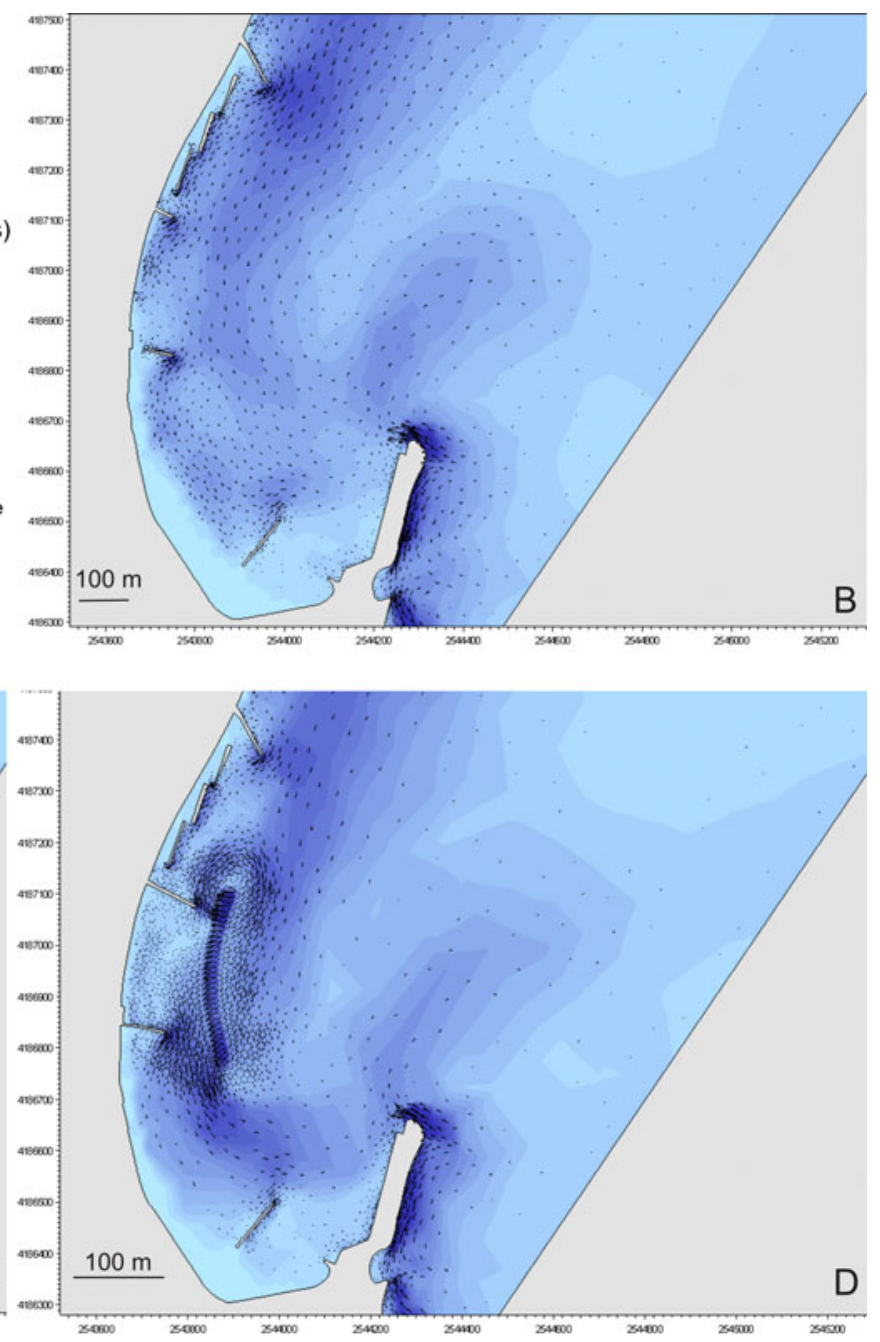

the bay without any intervention, $\mathbf{c}$ southern part of the bay using a first project solution (with a shorter northern groin), $\mathbf{d}$ southern part of the bay using a second project solution (with a longer northern groin) 
keeping the autochthonous materials for the recharge that will have undertaken by the local administration, reducing expenses as far as possible. From this perspective, the sediments along the Termini Imerese Gulf (northern Sicily), amount to tens million cubic metres and are compatible to the ones along the shoreface and seabed of the Bay of Giardini Naxos both from a granulometric (according to (James 1975)), and from a compositional viewpoint (light minerals, heavy minerals, mineral aggregates, lithic and shell fragments; Fig. 5).

To date, there is no proven method for computing the amount of overfill required to satisfy project dimension. Until now the use of overfill criteria developed by (James 1975) has given the best results in most cases. This graphic procedure, using the comparison of mean size and the sorting of both native and borrowed sediments, enables us to define the second one as stable or unstable on the native beach.

To complete this analysis, the compositional analysis of the sediments was also performed (Randazzo et al. 1998).

Finally, the study of the winds and the wave buoy of Catania has helped to define the local swell (MIKE 21) and its reduction by the submerged barrier.

Environmentally, the area involved at first lacked macroscopic flora and fauna, and there were few zoomacrobenthic elements with any real evidence of a biological chain, while

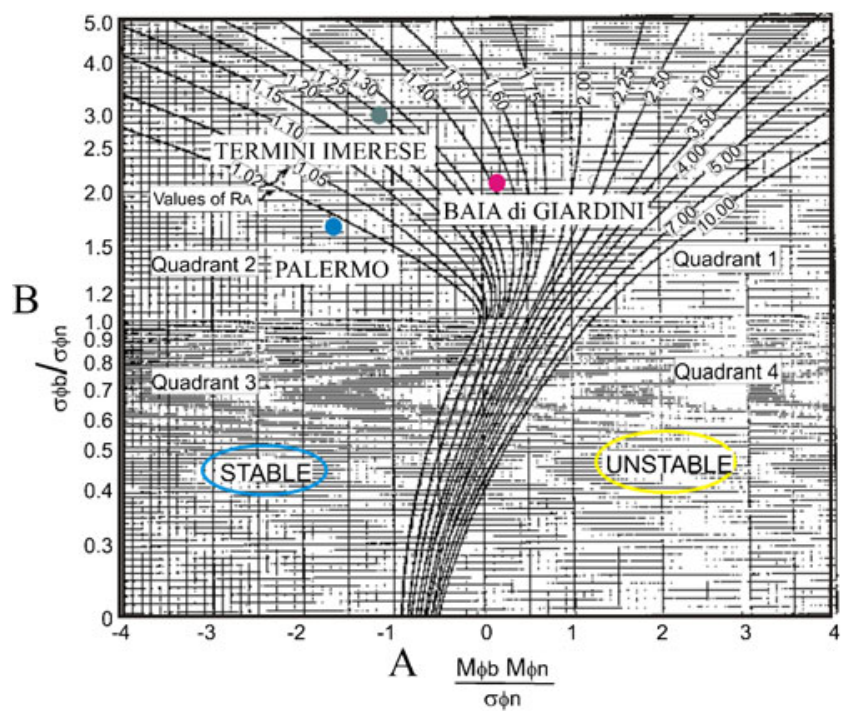

Fig. 5 JAMES 1975 ratio, evaluating the stability of the borrowed sediments for beach replenishment. The comparison was made using a composite sample coming from each of the three deposits available (Termini Imerese, Palermo and the Bay of Giardini) and the composite sample from the shoreface of the beach taken during the first phase of the project (end of the replenishment December 2004). The sediment used for the comparison is that still stable on the beach. The areas involved in the second and the third phases, residually, present very coarse sand and cobbles which do not represent the sediments originally present on the two tracts of the beach and the quality itself of the beach sought by the technicians working on the problem functionally the area was unsuitable for swimming, since the uncomfortable top of the outcrop of a quartzy sandstone level of the Capo D'Orlando Flysch emerged.

\section{Conclusions: the lesson learnt and its regional applicability}

The experience of Giardini Naxos highlights certain important aspects that should be taken into account for the correct management of the coast where beaches are not only the interface between land and sea but also a driving force in the development of the tourist system as a whole.

It is evident that in the beginning the town of Giardini Naxos has certainly worked very well, providing funds for an independent study of the coastline, but also by adhering to all European initiatives that monitor the area on a technical, social, and economic basis (M.E.S.S.I.N.A. INTERREG III C West Zone Programme. Managing European Shoreline and Sharing Information on Near-shore Areas. European Union 2003; Eurosion European 2004).

The project conducted in Giardini Naxos showed an excellent-quality structure, and a submerged artificial barrier (reef) still in good working order and showing an excellent capacity to mitigate wave action. It remains clear, however, that in the absence of its completion and without replenishment, the material initially distributed gradually drifted away from the beach, settling mainly along the same submerged artificial reef.

At this stage, the work carried out has held the line, so that, after the partial construction of the reef barrier, the waterfront has remained fixed and a thin strip of beach is still there. Nevertheless, this is insufficient to create new impetus for one of the major tourist destinations in the Mediterranean, where the tourist sector itself, based on the sun-and-beach tourist model, has resulted in a substantial surge in urbanization and in a drastic transformation of the landscape, especially in coastal areas. It is evident, from the local monitoring, performed for about 6 months after the end of the first two phases that the nourished material was almost lost, that continuous management at local level is needed.

For this reason, it is vital that local governments establish, either alone or in association with neighbouring ones, the monitoring and acquisition of technical knowledge on the evolution of its coastal area: in terms of urban growth (residential buildings, linear structures, lidos, and sports facilities) and in terms of variation in the quality and quantity of the beach.

On a regional level, planning needs to take into account two aspects: the impact that a given work may have on the surrounding areas, offering a programme set in the context of a sedimentological cell (see the end (Eurosion European 
2004)), and plan actions that will have a major impact on the tourist areas while allowing the work to be completed within a reasonable time.

Unfortunately, this did not happen in Giardini Naxos, where, the first allotments of funds in 2004 were followed by an inadequate sum in 2008, when the Sicilian Regional Government began to invest in the protection of other areas, without completing the projects that were still in progress.

This technical-administrative process has highlighted the weaknesses of the Coastal Management Plan, which is far removed from local administration and cannot provide operational instructions for local intervention. These often have no valid reason to be undertaken and are not adequately supported by local and regional technical data.

Because this was partially successful, after the funding of the 17th intervention (Giardini Naxos was one of these), the Sicilian Regional Government adopted a more structured plan that aimed to cover the entire coastal strip: the Hydrogeological Structure Plan for coastlines. This tool, based mainly on the comparison of maps and data from the literature or from the press, is an excellent picture of the state of the environment, but does not enable us to track the time course of the coastal system and respond accurately to its needs, which often change during a single season.

In view of this territorial situation, it is crucial that any objective and implemented plan be based on a constant flow of information between the local and regional authorities, who should undertake their planning on a higher level than the municipalities so that action taken on one side does not damage surrounding areas.

After having acknowledged the technical problems, politicians started to take into consideration a reform of coastal management, in a broader system regarding the management of maritime government properties and trying to link in programmes for the economic development of the beach.

Following this first experience, in the year 2010, the president of the Sicilian Regional Government focused on the review of this plan, introducing, in the Coastal Management Plan, the need for a continuous exchange of objective technical information between the local administration and regional government and especially by introducing the need to monitor the structures built and the most stressed areas. The Coastal Management Plan is being carried out by the government, but several local initiatives are testing the validity of the system.

Of vital importance to this liaison is the need to deal with beaches in a sustainable way. This will be achieved only through management strategies which work more closely with natural processes, and are integrated within strategic planning that encompasses the coastal zone (Jemmings 2004).
Acknowledgments We would also like to thank P3A Engineering for having allowed us to use some of their images for our project.

Finally thank you to the Municipality of Giardini Naxos which allowed us to use all the material produced in the last 10 years for the study of the coast of the Bay of Giardini Naxos

\section{References}

A.A.S.T. (2010) Dati turistici Provincia di Messina. Azienda Autonoma Siciliana Turismo

Amore C, Di Geronimo S, Giuffrida E, Randazzo G (1988) Atlante delle spiagge italiane, Fogli 262 (M. Etna) e 253 (Castroreale p.p.) C.N.R., P.F. Consevazione del suolo, Sott. Dinamica dei litorali, Roma, map

Chelussi I (1912) Di alcuni saggi di fondo del Mediterraneo. Bollettino della Società Geologica Italiana. Vol. XXXI, Roma, Italia, pp 79 88

D'Arrigo A (1936) Baia di Taormina in Ricerche sul regime dei litorali nel Mediterraneo. Consiglio Nazionale delle Ricerche, Comitati per la Geologia e per l'Ingegneria. Roma, Italia, pp 114-116

Deboudt P (1999) Les hommes et la lutte contre l'érosion côtiére sur le littoral de Sangatte (Pas-de-Calais, France). Revue de Géographie de Lyon 74(1):65-74

Deboudt P (2002) Géo-histoire de la lutte contre l'érosion côtiére sur le littoral du Pas-de-Calais. In Malé Zieux, J. (coord.), Le Milieu Littoral. Comité des Travaux Historiques et Scientifiques. pp 221-237

Eurosion European Programme (2004) Living with coastal erosion in Europe: Sediment and Space for Sustainability. European Community Office of Official Publications

James JR ((1975)) Techniques in evaluating suitability of borrow material for beach nourishment. In: Coastal Engineering Research Center, U.S. Army Engineer Waterways Experiment Station. Vicksburg, Mississippi

Jemmings S (2004) Coastal tourism and shoreline management. Ann Tourism Res 31(4):899-922

M.E.S.S.I.N.A. (2006) INTERREG III C West Zone Programme. Managing European Shoreline and Sharing Information on Near-shore Areas. European Union 2003-2006

Meur-Férec C, Deboudt P, Morel V (2008) Coastal risks in France: an integrated method for evaluating vulnerability. J Coast Res 24 (2B): 178-189

Miossec A (1998) Erosion marine, les réponses. Mappemonde 52 (4):1-6

Randazzo G, Lanza S (2011) Improvements to a Coastal Management Plan in Sicily (Italy): new approaches to borrow sediment management. J Coast Res Spec (64):1357-1361

Randazzo G, Lo Curzio M, Lanza S (2008) First step in strategic environment assessment (SEA) adoption for coastal planning in Sicily (South Italy). J Coast Conserv 12(3):161-168

Randazzo G, Stanley DJ, Di Geronimo SI, Amore C (1998) HumanInduced Sedimentological changes in Manzala Lagoon, Nile Delta, Egypt. Environ Geol 36(3-4):235-258

Tintoré J, Medina R, Pujol LG, Orfila A, Vizoso G (2009) Integrated and interdisciplinary scientific approach to coastal management. Ocean Coast Manag 52:493-505

Van Vuren S, Matthjis K, Jorissen RE (2004) Coastal defense and societal activities in the coastal zone: Compatible or conflicting interests? 20(2):550-561 